\title{
Outcomes and survival prediction models for severe adult acute respiratory distress syndrome treated with extracorporeal membrane oxygenation
}

\author{
Sacha Rozencwajg ${ }^{1,2}$, David Pilcher ${ }^{3,4}$, Alain Combes ${ }^{1,2}$ and Matthieu Schmidt ${ }^{1,2^{*}}$
}

\begin{abstract}
Extracorporeal membrane oxygenation (ECMO) for severe acute respiratory distress syndrome (ARDS) has known a growing interest over the last decades with promising results during the 2009 A(H1N1) influenza epidemic. Targeting populations that can most benefit from this therapy is now of major importance. Survival has steadily improved for a decade, reaching up to 65\% at hospital discharge in the most recent cohorts. However, ECMO is still marred by frequent and significant complications such as bleeding and nosocomial infections. In addition, physiological and psychological symptoms are commonly described in long-term follow-up of ECMO-treated ARDS survivors. Because this therapy is costly and exposes patients to significant complications, seven prediction models have been developed recently to help clinicians identify patients most likely to survive once ECMO has been initiated and to facilitate appropriate comparison of risk-adjusted outcomes between centres and over time. Higher age, immunocompromised status, associated extra-pulmonary organ dysfunction, low respiratory compliance and non-influenzae diagnosis seem to be the main determinants of poorer outcome.
\end{abstract}

Keywords: Extracorporeal membrane oxygenation, Acute respiratory distress syndrome, Outcome, Predictive survival models, ECMO-related complications

\section{Background}

Extracorporeal membrane oxygenation (ECMO) is considered a therapeutic option for patients with severe acute respiratory distress syndrome (ARDS) with refractory hypoxemia or unable to tolerate volume-limited strategies $[1,2]$. Use of ECMO has been growing exponentially in the last decade [3], encouraged by promising results from the multi-centred randomized controlled trial CESAR [4] and benefits described during the influenza $\mathrm{A}\left(\mathrm{H}_{1} \mathrm{~N}_{1}\right)$ pandemic. In addition, major progress in technology (e.g. smaller devices, heparin-coated circuits, biocompatible membranes, dual lumen cannulae) [5] and network organization, with referral centres and

\footnotetext{
* Correspondence: matthieu.schmidt@aphp.fr

'Sorbonne Universités, UPMC Univ Paris 06, INSERM, UMRS_1166-ICAN, Institute of Cardiometabolism and Nutrition, 75651 Paris Cedex 13, France

${ }^{2}$ Assistance Publique-Hôpitaux de Paris, Pitié-Salpêtrière Hospital, Medical Intensive Care Unit, 75651 Paris Cedex 13, France

Full list of author information is available at the end of the article
}

mobile ECMO teams available 24/7, have both contributed to exponentially increase the use of ECMO (Fig. 1). However, despite these improvements, ECMO is still marred by a high rate of complications such as bleeding, thrombosis and nosocomial infection [6-8]. Moreover, ECMO-treated survivors exhibit significant rates of longterm neuro-psychological and/or physical impairment [7]. To date, most of the severe ARDS patients are either referred to ECMO referral centres $[4,9]$ or cannulated in a distant hospital by a mobile ECMO team $[4,10,11]$. Because this therapy is costly and exposes patients to significant complications, a number of prediction models have been developed recently to help clinicians identify patients most likely to survive once ECMO has been initiated and to facilitate appropriate comparison of risk-adjusted outcomes between centres and over time. This review will describe actual short-term and long-term outcomes of patients with severe ARDS treated with 


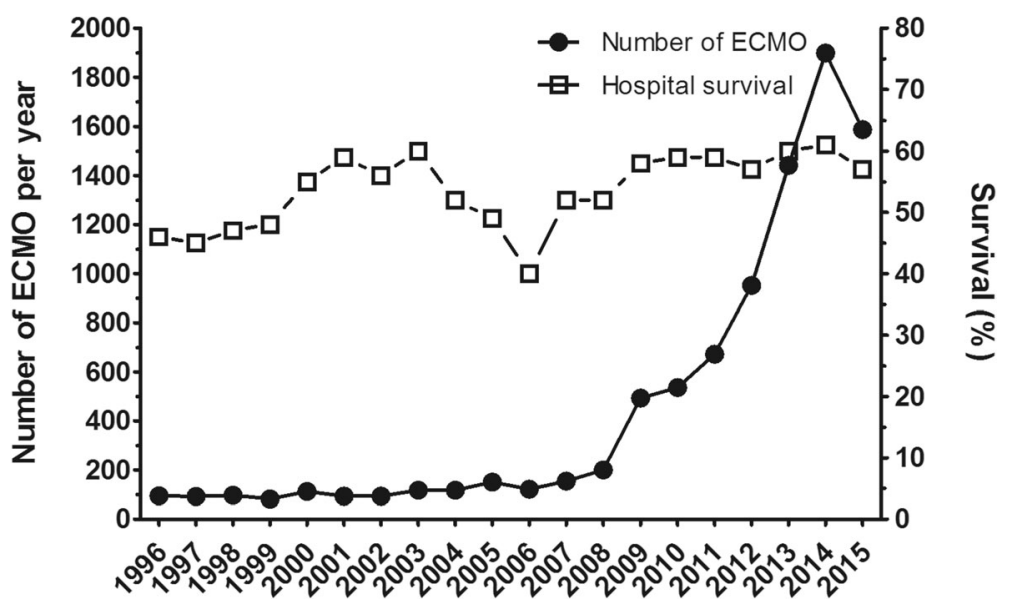

Fig. 1 Number of annual adult respiratory cases treated by venovenous ECMO from 1996 to 2015 and the relative hospital survival rate. Adapted from the ELSO ECLS Registry Report [3]. ECMO extracorporeal membrane oxygenation

ECMO and summarize the characteristics and performance of published survival prediction models.

\section{Outcomes of severe ARDS patients with and without ECMO}

\section{Outcomes of severe ARDS treated with "conventional"} management

The past two decades have seen significant progress in ARDS management. A more accurate definition has been proposed [12] and major progress has been achieved in understanding the ARDS pathophysiology [13-15] and ventilator-induced lung injury $[16,17]$. In addition, protective-lung mechanical ventilation [18] and adjuvant therapies such as prone positioning [19] and neuromuscular blockers [20] have contributed to improvements in overall ARDS mortality. Despite this, the pooled mortality of ARDS (covering all levels of ARDS severity) remains high, even more so in observational studies (48.2\%) than in randomized controlled trials (37.5\%) [21]. The mortality for severe ARDS is higher still, at 50\% [12, 22, 23]. In addition, the burden of ARDS is still perceptible years after ICU discharge, with notable impairment of quality of life [24]. Reported long-term sequelae include ICUacquired weakness, exercise limitation, frozen shoulders, vocal-cord dysfunction or recurrent reactive airways disease which may contribute to social isolation, psychological morbidity and sexual dysfunction [24]. In a large cohort of 109 patients with ARDS, 51\% of patients reported at least one episode of depression and/or severe anxiety within 5 years of follow-up [24]. Nevertheless, 77\% of patients returned to work; almost all to their original work 5 years after ICU discharge.

\section{Outcomes of ARDS treated with venovenous ECMO}

Outcomes of patients with ARDS on ECMO have improved steadily over a decade (Fig. 1) thanks to the progress of the devices [5] and better prevention of ECMO-related complications such as bleeding.

The first large international multicentre database on ECMO for severe ARDS was provided by Brogan et al. [25] using a registry issued from a collaborative international network (Extracorporeal Life Support Organization (ESLO)). The data, collected between 1986 and 2006, covered 1473 patients with a median age of 34 years, 78 of whom were treated with venovenous ECMO (VV-ECMO) with a median time of support of 154 hours. They reported an all-cause mortality of $50 \%$. Risk factors associated with a poorer outcome were advanced age, days on mechanical ventilation prior to ECMO and decreased patient weight. These results were relatively consistent with the CESAR trial [4], which reported 63\% survival without severe disability at 6 months. In this trial, conducted between 2001 and 2006 in the United Kingdom, 180 patients with severe ARDS were either randomized into ECMO (after transfer to a referral "ECMO centre") or to conventional management at the referring hospital. These patients suffered from severe and potentially reversible ARDS. Their median age was 40 years (mean APACHE II 20), with a primary diagnosis of pneumonia in $66 \%$. The same year, Australia and New Zealand Extracorporeal Membrane Oxygenation (ANZ ECMO) [26] reported excellent results with a cohort of influenza $\mathrm{A}\left(\mathrm{H}_{1} \mathrm{~N}_{1}\right)$-related ARDS patients. They reported $78 \%$ of patients weaned from ECMO and 71\% ICU discharge survival despite extreme severity before cannulation (median lowest $\mathrm{PaO}_{2} / \mathrm{F}_{\mathrm{I}} \mathrm{O}_{2}$ ratio $56 \mathrm{mmHg}, \mathrm{pH}$ 7.2, $\mathrm{PaCO}_{2}$ $69 \mathrm{mmHg}$ and modified acute lung injury score of 3.8). These results should, however, be interpreted with caution because influenza $A\left(\mathrm{H}_{1} \mathrm{~N}_{1}\right)$-related ARDS has a better prognosis than other causes of ARDS [27, 28]. More recently, Schmidt et al. [6] reported the outcome 
of 140 patients from three French ICUs. Ninety-five per cent of patients received VV-ECMO with a median time between intubation and ECMO cannulation of 5 (1-11) days. Bacterial pneumonia was the main cause of ARDS (45\%). Influenza $\mathrm{A}\left(\mathrm{H}_{1} \mathrm{~N}_{1}\right)$-related ARDS was noted in $26 \%$. Survival rates were respectively $64 \%$ and $60 \%$ at ICU discharge and 6 months. A cohort of 2355 patients extracted from the international ELSO registry [27] has also been studied recently. ECMO therapy was initiated after a median of 57 hours of mechanical ventilation, with $49 \%$ of patients receiving neuromuscular blocker agents, $20 \%$ inhaled nitric oxide and 10\% high-frequency oscillatory ventilation. Fifty-seven per cent of patients were alive at hospital discharge after a median of 170 hours on ECMO.

\section{Long-term outcome}

The few studies of long-term outcome after ECMO are described in Table 1. The frequent use for young adults with no pre-existing co-morbidities should foster clinicians to measure long-term impact of this therapy. The long-term effects of ECMO have been evaluated broadly in three areas: respiratory function; psychological impairment; and quality of life.

Post-ECMO respiratory impairment can be assessed in three domains: lung capacity assessed by lung function tests; parenchymal changes observed on imaging; and respiratory symptoms. In the CESAR trial [4], lung function tests, performed 6 months post ECMO, indicated relatively preserved lung capacity (forced vital capacity $79.6 \%$ predicted, peak expiratory flow rate $54.5 \%$ predicted) and were no different to the conventional management group. Similarly, Lindén et al. [29] reported lung function measured at varying time points at least 1 year post ECMO in a cohort of 21 survivors of bacterial pneumonia-related ARDS treated with ECMO. They described slightly impaired lung function with a mildly obstructive pattern (forced expired volume at 1 second $<80 \%$ ). Measurement of $\mathrm{SpO}_{2}$ during exercise tests was low in $43 \%$ patients and a reduced DLCO (70\% of predicted value) was noted in $65 \%$. In addition, radiological changes compatible with interstitial fibrosis were reported in $76 \%$ of the population. In the study by $\mathrm{Li}$ et al. [30], 15 patients underwent 1-year follow-up with repeated computed tomography after severe ARDS requiring VV-ECMO. Eighty-seven per cent of patients exhibited similar changes, with more severe damage distributed in the ventral region. In the context of influenza $\mathrm{A}\left(\mathrm{H}_{1} \mathrm{~N}_{1}\right)$-related ARDS, similar findings were reported by Luyt et al. [31]. Lung function tests on 67 patients demonstrated a mild impairment of lung-diffusion properties (DLCO below the fifth percentile of normal values) in both ECMO and non-ECMO survivors with no difference between both groups. No obstructive lung disease was noted and arterial blood gases at rest and after exercise were within normal ranges. However, 75\% of patients in the ECMO group suffered from moderate dyspnoea during strenuous exercise at 1 year [31]. Lastly, it is notable that most patients in both groups had returned to work, and one-third practised sport regularly [31].

Health-related quality of life (HRQoL) evaluation assesses both the physical and psychological impact of ECMO among survivors. Lindén et al. [29] first described HRQoL in their cohort of 21 long-term survivors of severe ARDS and ECMO, focusing on the respiratory symptoms, and showed higher scores on the St George's Respiratory Questionnaire (SGRQ) than normal values, indicating subjective respiratory problems with an impact on daily life. These findings contrast with the CESAR trial where equivalent SGRQ scores were reported in both groups. Most of the studies used the 36-Item Short-Form Health Survey (SF-36) [32] to assess HRQoL. The physical domain scores of the SF-36 reported mobility limitation or self-care restriction in about $20-30 \%$ of survivors [4, 31,33], which may mostly be due to ICU-acquired limb weakness, considered "slight to moderate" when compared with age-matched and sex-matched population controls [6, 31]. Psychological impairment may also jeopardize long-term quality of life of ECMO survivors. Others domains of the SF-36 evaluate vitality, social functioning and emotional status. Data regarding psychological impact of ECMO for ARDS survivors are scarce. However, they were globally impaired when compared with agematched and sex-matched population controls $[4,6]$. These data were consistent with those of Hodgson et al. [33], who reported a $27 \%$ decrease in SF-36 mental component scores in ARDS patients who received ECMO. Finally, 25-34\% of ECMO patients reported long-term anxiety and depression symptoms, with $15 \%$ considered at risk of post-traumatic stress disorder $[4,6]$. These results were similar to those reported in other post-ICU studies [34-36].

In conclusion, HRQoL seems to be significantly impaired after ECMO for severe ARDS. This must be interpreted with caution, however, because it may be attributable to the patient's ICU length of stay and underlying disease rather than to ECMO itself. HRQoL data showing no difference between ECMO and non-ECMO severe ARDS patients tend to confirm this hypothesis [33].

\section{ECMO-related complications}

The two most important and commonly described ECMO-related adverse events are bleeding and nosocomial infection. 
Table 1 Studies relating long-term outcomes after ECMO for severe ARDS

\begin{tabular}{|c|c|c|c|c|c|c|}
\hline \multirow[t]{2}{*}{ Study } & \multirow{2}{*}{$\begin{array}{l}\text { Cohort } \\
\text { enrolment }\end{array}$} & \multirow{2}{*}{$\begin{array}{l}\text { Total } \\
\text { population }\end{array}$} & \multicolumn{2}{|l|}{ Follow-up } & \multirow[t]{2}{*}{ Primary outcome } & \multirow[t]{2}{*}{ Long-term outcomes } \\
\hline & & & population & Median time & & \\
\hline Peek et al.[4] & $2001-2006$ & 68 & 52 & 6 months & $\begin{array}{l}\text { Death or severe disability at } \\
6 \text { months }\end{array}$ & $\begin{array}{l}\text { Lung function evaluated with PFT, overall health status, HRQoL, depression } \\
\text { and anxiety symptoms }\end{array}$ \\
\hline Lindén et al.[29] & Before 2009 & 37 & 21 & $26(12-50)$ months & $\begin{array}{l}\text { Pulmonary morphology } \\
\text { (CT scan) }\end{array}$ & Lung function (PFT), pulmonary symptoms (SGRQ) \\
\hline Hodgson et al.[33] & 2009-2011 & 34 & 15 & 9 (8-19) months & HRQoL (SF-36) & Related ECMO complications, survival, discharge destination, return-to-work status \\
\hline Luyt et al.[31] & Winter 2009 & 67 & 12 & 12 months & HRQoL (SF-36) & $\begin{array}{l}\text { Symptoms and activities since hospital discharge, weight and muscle-strength } \\
\text { testing, lung morphology (CT scan), anxiety and depression (HAD scale), symptoms } \\
\text { of PTSD (IES) }\end{array}$ \\
\hline Schmidt et al.[6] & 2008-2012 & 140 & 67 & 17 (11-28) months & $\begin{array}{l}\text { Factors associated with } \\
\text { death at } 6 \text { months }\end{array}$ & $\begin{array}{l}\text { HRQOL (SF-36 score), pulmonary symptoms (SGRQ), anxiety and depression } \\
\text { (HAD scale), symptoms of PTSD (IES) }\end{array}$ \\
\hline Li et al.[30] & 2009-2012 & 29 & 8 & 12 months & Pulmonary morphology & \\
\hline
\end{tabular}

ARDS acute respiratory distress syndrome, ECMO extracorporeal membrane oxygenation, HAD hospital anxiety and depression, HRQoL health-related quality of life, IES Impact of Event Scale, PFT pulmonary function tests, PTSD post-traumatic stress disorder, SF-36 Medical Outcome Short-Form, SGRQ St George's Respiratory Questionnaire 
Bleeding occurs in about $20 \%$ of patients on ECMO with various degrees of severity (i.e. cannula haemorrhage, spontaneous epistaxis, gastrointestinal or intra-cranial bleeding, etc.) [37, 38]. The main mechanisms are anticoagulation, thrombocytopenia and coagulation factor consumption. ECMO circuits are also responsible for impaired platelet function [39] and biological acquired von Willebrand syndrome (AVWS) [40, 41]. However, a study by Abrams et al. [42] reported that severity of critical illness and platelet count at the time of cannulation, rather than ECMO duration, were the best predictors for development of severe thrombocytopenia while receiving ECMO for respiratory failure. Consumption of red blood cells has been reported as approximately 1 unit per ECMO-day while $17 \%$ of patients underwent surgery for bleeding issues [43]. Application of a restrictive transfusion policy on ECMO is possible by implementing a lower aim for systemic anticoagulation, a fixed transfusion threshold of $7 \mathrm{~g} / \mathrm{dl}$ and auto-transfusion during decannulation [44].

Nosocomial infections are also very frequent in ECMO patients. Their incidence varies widely from 11.7 to $64 \%$ $[1,45,46]$, equivalent to $11.9-75.5$ infections/1000 ECMO-days. However, these data are lacking in the specific VV-ECMO population. Among these infections, the two most common were bloodstream infections and ventilator-associated pneumonia with a median of 15 / 1000 ECMO-days and 4/1000 ECMO-days respectively when pooling several studies [46-49]. Duration on $\mathrm{ECMO}$ and patient's severity were independent risk factors. One should note that the definition of "ECMOrelated infection" and the diagnostic techniques for cannula-related infection are not consistent and may account for differences observed between different studies. In addition, antibiotic prophylaxis, routine bacterial surveillance and continuous antibiotics are frequently used in ECMO centres despite no evidence of their benefit [50].

Neurological events occurred frequently in patients on VV-ECMO. Among 135 consecutive patients who had received VV-ECMO, 18 (15 assessable) developed cerebral complications on ECMO: cerebral bleeding in 10 patients (7.5\%), ischemic stroke in three patients $(2 \%)$ or diffuse microbleeds in two patients (2\%). Intracranial bleeding, the most frequent complication, occurred early and was associated with higher mortality. Because intracranial bleeding was independently associated with rapid hypercapnia decrease, ECMO onset should be avoided in this situation, but its exact role remains to be determined [51].

Other ECMO-related complications include thrombosis, especially deep vein thrombosis in the cannulated vessels following ECMO. The incidence was estimated at 8.1/ 1000 cannula-days and routine venous Doppler ultrasound following decannulation in the VV-ECMO population has been advocated [8]. In addition, haemolysis is commonly observed during VV-ECMO. A recent study of 207 paediatric patients with ECMO reported at least one episode of haemolysis in $66 \%$ patients. Although haemolysis is frequently considered minor, these patients were more likely to experience a longer ECMO run and require more blood products. After controlling for age, weight, paediatric index of mortality and diagnosis, patients with severe haemolysis were more likely to die in the ICU and in hospital (odds ratio (OR) 6.34, 95\% confidence interval (CI) 1.71-23.54; $p=0.006$ ) [52]. In adults, further data are needed to investigate the causes of haemolysis on ECMO and to elucidate its influence on morbidity and mortality.

\section{Survival prediction models}

\section{Objectives of these scores}

Because of the significant numbers of ECMO-related complications, the high rates of long-term physical and psychological impairment, and the human and financial cost, identifying specific populations who could benefit most from this therapy is crucial. All of these scores have been derived only from populations already on ECMO. As such, they should be considered most appropriate for predicting who will survive once ECMO has been initiated, comparing outcomes between units and over time, or helping inform clinicians, family members and even occasionally patients themselves of likely outcomes. Without a population of patients who did not receive ECMO, none of the scores so far described can be considered directly applicable for choosing which patients should or should not receive ECMO. However, given the fact that most of the predictive variables described have been recorded during the immediate pre-ECMO period, it is likely that the same factors which predict survival in populations who are on ECMO may also be helpful to select patients for consideration of ECMO.

\section{Survival prediction scores}

Over the past 3 years, seven different pre-ECMO survival prediction scores have been published $[6,27,28$, 53-56]; the characteristics of these scores are summarized in Table 2 and Fig. 2. The risk factors taken into account in these models can be divided into four major determinants: demographic characteristics; organ dysfunction; characteristics and management of respiratory failure; and initial diagnosis.

\section{Demographic characteristics}

In all models but ECMOnet and the two most recent published scores $[6,27,28,54]$, age was an independent risk factor. In the PRESERVE and Roch et al. scores [27, 28], being younger than 45 years old was associated with a better prognosis, while a major mortality risk was described for patients over 60 years of age. Immunocompromised 
Table 2 Survival predictive models for patients on W-ECMO for ARDS

\begin{tabular}{|c|c|c|c|c|c|c|c|c|}
\hline Score & Population & $\begin{array}{l}\text { Number of } \\
\text { patients }\end{array}$ & $\begin{array}{l}\text { Number of } \\
\text { centres }\end{array}$ & $\begin{array}{l}\text { Cohort } \\
\text { enrolment }\end{array}$ & Pre-ECMO items & & $\begin{array}{l}\text { Internal validation's } \\
\text { AUROC }\end{array}$ & $\begin{array}{l}\text { External validation's } \\
\text { AUROC }\end{array}$ \\
\hline $\begin{array}{l}\text { ECMOnet score: } \\
\text { Pappallardo et al. [53] }\end{array}$ & $\mathrm{A}(\mathrm{H} 1 \mathrm{~N} 1)$ influenza-related ARDS & 60 & 14 & Winter 2009 & $\begin{array}{l}\text { 1. Pre-ECMO LOS } \\
\text { 2. Bilirubin } \\
\text { 3. Creatinine }\end{array}$ & $\begin{array}{l}\text { 4. Haematocrit level } \\
\text { 5. Mean arterial pressure }\end{array}$ & 0.86 & $\begin{array}{l}0.69^{\mathrm{a}} \\
0.60^{\mathrm{b}}\end{array}$ \\
\hline $\begin{array}{l}\text { PRESERVE score: } \\
\text { Schmidt et al. [6] }\end{array}$ & Severe ARDS & 140 & 3 & $2008-2012$ & $\begin{array}{l}\text { 1. Age } \\
\text { 2. Body mass index } \\
\text { 3. Immunocompromised } \\
\text { 4. SOFA score }\end{array}$ & $\begin{array}{l}\text { 5. Days of MV } \\
\text { 6. Prone positioning } \\
\text { 7. PEEP } \\
\text { 8. Plateau pressure }\end{array}$ & 0.89 & $\begin{array}{l}0.68^{b}, \\
0.75^{c}\end{array}$ \\
\hline $\begin{array}{l}\text { RESP score: } \\
\text { Schmidt et al. [27] }\end{array}$ & $\begin{array}{l}\text { Acute respiratory } \\
\text { failure }\end{array}$ & 2355 & 280 & $2000-2012$ & $\begin{array}{l}\text { 1. Age } \\
\text { 2. Immunocompromised } \\
\text { 3. Days of MV } \\
\text { 4. Diagnosis } \\
\text { 5. Central nervous system } \\
\text { dysfunction } \\
\text { 6. Acute associated } \\
\text { (non-pulmonary) infection }\end{array}$ & $\begin{array}{l}\text { 7. Neuromuscular } \\
\text { blockade agents } \\
\text { 8. Nitric oxide use } \\
\text { 9. Bicarbonate infusion } \\
\text { 10. Cardiac arrest } \\
\text { 11. PaCO } \\
\text { 12. Peak inspiratory } \\
\text { pressure }\end{array}$ & 0.74 & $\begin{array}{l}0.92^{d}, \\
0.81^{\prime}\end{array}$ \\
\hline Roch et al. [28] & $\begin{array}{l}\text { ARDS brought to a } \\
\text { referral centre }\end{array}$ & 85 & 1 & 2009-2013 & $\begin{array}{l}\text { 1. Age } \\
\text { 2. SOFA score } \\
\text { 3. Influenza }\end{array}$ & & 0.80 & No \\
\hline Enger et al. [54] & ARDS & 284 & 1 & 2008-2013 & $\begin{array}{l}\text { 1. Age } \\
\text { 2. Immunocompromised } \\
\text { 3. Minute ventilation }\end{array}$ & $\begin{array}{l}\text { 4. Haemoglobin } \\
\text { 5. Lactate }\end{array}$ & 0.75 & No \\
\hline Liu et al. [55] & ARDS & 38 & 1 & 2009-2014 & $\begin{array}{l}\text { 1. Barotrauma }{ }^{e} \\
\text { 2. Underlying lung disease }\end{array}$ & & - & - \\
\hline $\begin{array}{l}\text { W-ECMO mortality score: } \\
\text { Cheng et al. [56] }\end{array}$ & Severe ARDS & 116 & 1 & $2007-2015$ & $\begin{array}{l}\text { 1. Immunocompromised } \\
\text { 2. SOFA score } \\
\text { 3. Days of MV }\end{array}$ & & 0.76 & No \\
\hline
\end{tabular}

${ }^{a}$ Validation in a cohort of 74 patients with $A(H 1 N 1)$ influenza-induced ARDS

balidation in the cohort of Enger et al. [54]

Galidation in the cohort of Kleinzing et al. [60].

dValidation in the PRESERVE cohort of Schmidt et al. [6]
Dation

ealidation in the PRESERVE cohort of Schmidt et al. [6]

ARDS acute respiratory distress syndrome, AUROC area under receiver operating characteristic curve, ECMO extracorporeal membrane oxygenation, LOS length of stay, MV mechanical ventilation, PEEP positive end-

expiratory pressure, RESP Respiratory Extracorporeal Membrane Oxygenation Survival Prediction, SOFA Sequential Organ Failure Assessment, $V V$ venovenous 


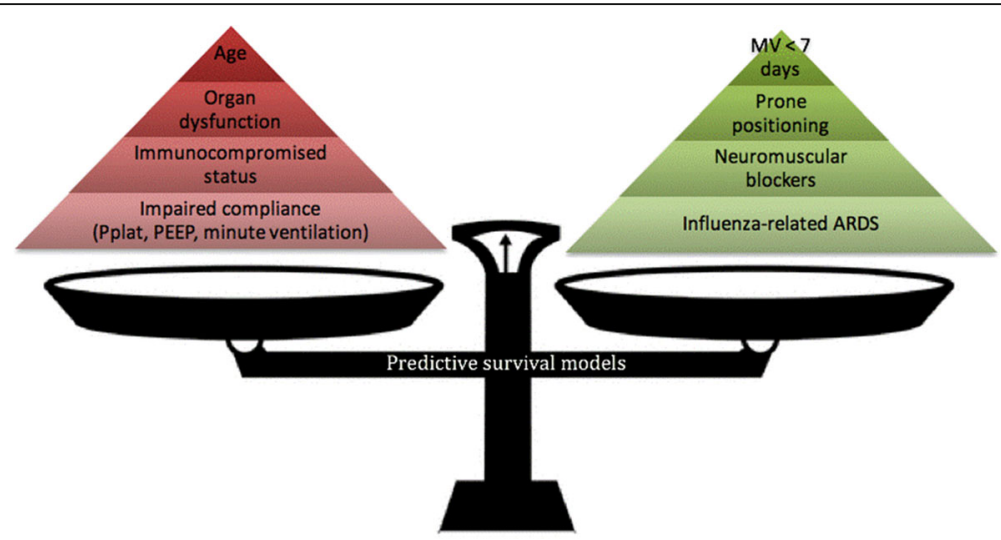

Fig. 2 Pre-ECMO factors associated with mortality on W-ECMO according to published predictive survival models. Red pyramid, risk factors; green pyramid, protective factors: the higher the factor, the heavier impact on mortality according to published predictive survival models. ARDS acute respiratory distress syndrome, $M V$ mechanical ventilation, Pplat, plateau pressure PEEP positive end-expiratory pressure

status was consistently associated with a poorer outcome in four out of the seven models [6, 27, 54, 56]. For instance, chronic immunosuppression was associated with increased mortality both in Enger et al.'s [54] score (OR 2.6, 95\% CI 1.3-5.2) and the VV-ECMO [56] mortality score (OR 2.9, 95\% CI 1.1-7.9). Liu et al. [55] found an underlying lung disease (i.e. COPD, interstitial lung disease and lung cancer) to be an independent risk factor for mortality (OR 12.2, 95\% CI 1.2-122.2; $p=0.033$ ). In no other models were co-morbidities such as chronic organ dysfunction or diabetes identified as associated with poorer outcome. However, there were so few patients with these conditions that it is difficult to raise any conclusion about their impact on outcome.

\section{Acute organ dysfunction}

The number of pre-ECMO organ dysfunctions is unsurprisingly a significant predictive factor. In the Roch et al., PRESERVE, Enger et al. and VV-ECMO mortality scores $[27,28,54,56]$ the SOFA score was used as an organ failure surrogate, whereas mean arterial pressure, serum creatinine, bilirubin and haematocrit levels were used in the ECMOnet score [53]. Lastly, pre-ECMO central nervous system dysfunction was associated with a poorer outcome in the RESP score [27]. In recent retrospective cohorts, SOFA score $>15$ was constantly associated with higher mortality [56-58]. However, it is worth noting that pre-ECMO neurological status assessed by the Glasgow Coma Scale score is frequently difficult to evaluate in these patients due to high-dose sedative infusion, making reliability of this neurological SOFA score section questionable [28].

\section{Characteristics and management of respiratory failure}

Management of mechanical ventilation and adjuvant therapies for severe ARDS have greatly evolved during the last decade [18-20, 22, 23]. Amongst the patient cohorts from which scores have been developed, there was evidence of variation in pre-ECMO management, which influenced survival. For instance, only $49 \%$ of patients received preECMO neuromuscular blockade in the RESP study [27] compared with all patients in Roch et al.'s cohort [28]. Pre-ECMO nitric oxide and prone positioning were used, respectively, in 16 and 29\% of patients in the ECMOnet study [53] vs 90 and 60\% in the PRESERVE cohort [6]. Despite the variation in reported use of pre-ECMO adjuvant therapies, where these have been reported, the studies have demonstrated both prone positioning and provision of neuromuscular blockade to be associated with improved survival. These findings are consistent with non-ECMO literature [6, 27]. Duration of mechanical ventilation pre ECMO over 7 days has been significantly associated with a poor outcome in the RESP, the PRESERVE and the VV-ECMO mortality scores [6, 27, 56]. Interestingly, although hypoxemia is a major factor, which influences the decision to start VV-ECMO, no predictive score has shown it to be predictive of survival. Potential reasons for this include a direct effect of ECMO which reverses the adverse effects of hypoxia, bias induced by lack of information on "equally hypoxic" patients who do not receive ECMO or a type II statistical error as a result of the studies being underpowered to detect a small adverse effect from hypoxia. On the other hand, pre-ECMO direct and indirect markers of reduced compliance (e.g. high $\mathrm{PaCO}_{2}$, high peak inspiratory pressure, plateau pressure $>30 \mathrm{mmHg}$ or pre-ECMO barotrauma evidence) were strongly associated with poor outcome in the PRESERVE, RESP and VV-ECMO mortality scores $[6,27,56]$.

\section{Cause of respiratory failure}

Aetiology is important in determining the prognosis of ECMO-treated severe ARDS. Influenza-induced ARDS 
was consistently associated with better outcome in the Roch et al., PRESERVE and RESP scores (70, 83 and 70\% survival, respectively) $[6,27,28]$. The ECMOnet score [53], which was derived within this specific population, exhibited worse discrimination performance when it was applied in an all-cause ARDS population (area under the ROC curve of 0.60 in the external cohort validation vs 0.86 in the original cohort). With the exception of the RESP score [27], which showed that certain diagnoses such as "aspiration pneumonitis" had particularly good survival, patient numbers in most studies have been too small to detect significant relationships between other specific diagnoses and outcome.

\section{Prediction model limitations and performance}

All scores seem to perform better compared with classical ICU severity scores $[6,27,28,53,54]$. However, the differences in model composition illustrate heterogeneity of the ECMO databases in terms of size, population and data collected.

Some of these scores were specifically focused on dedicated populations, which limit applicability to other ARDS diagnosis. For instance, the ECMOnet score was built on an influenza $\mathrm{A}\left(\mathrm{H}_{1} \mathrm{~N}_{1}\right)$ ARDS cohort ventilated for less than 7 days [53], whereas Roch et al.'s score was designed for patients transferred to a referral centre for ECMO [28]. Variation in data collected in the ECMO databases influences the composition and the performance of survival prediction models, and we cannot rule out that other pre-ECMO items not collected in these databases might also impact on the prognosis. While pre-ECMO prone positioning and use of neuromuscular blockage agents are constituent parts of some scores [6, 27], other studies did not collect these variables [54-56] or found no statistical association with mortality [28]. Third, the statistical methodology used to construct the different scores is heterogeneous. All scores have used logistic regression techniques but none have employed mixed or random-effects models. Only two scores have used bootstrapping [27, 54] and only three out of seven have been validated externally $[6,27,53]$ (Table 1). Fourth, because patients' prognosis after ECMO has markedly improved over the last two decades, performance of these scores and derived predicted mortality rates might also change over time. Fifth, these models have been developed for patients already on ECMO and not validated for survival prediction in a general population of severe acute respiratory failure patients where ECMO has not (yet) been instituted. The models should therefore not be considered substitutes for clinical judgment. Lastly, caution should always be taken when using survival probabilities derived from these scoring systems to inform families and relatives on a patient's prognosis because
ECMO remains associated with devastating complications such as neurological bleeding which may occur despite favourable pre-ECMO score-based predicted survival.

\section{Conclusion}

Although the use of ECMO for severe refractory ARDS has markedly increased since 2009, in-hospital mortality remains high (from 35 to 45\%). In addition, despite major technological improvement of the devices, ECMO is still associated with numerous therapy-related complications and significant physical/psychological long-term impairment. These factors reinforce the need to perform ECMO in high volume [59] and expert referral centres with appropriate and accurate selection of patients who are mostly to obtain benefit over standard therapies. On the basis of a large development cohort, external validation and easily available web calculator (www.respscore.com), we recommend the RESP score to benchmark outcomes, to interpret variation in practice and to inform clinicians and families of likely outcomes for patients treated with ECMO for severe respiratory failure, and await with interest future prospective interventional studies to inform clinicians about when, how and on whom to perform ECMO.

\section{Acknowledgements \\ None. \\ Funding \\ Not applicable. \\ Availability of data and materials \\ Not applicable. \\ Authors' contributions \\ SR and MS were responsible for conception and design of the review. SR, $D P, A C$ and $M S$ were responsible for writing the manuscript. All authors read and approved the final manuscript. \\ Authors' information \\ SR is a fellow in the Medical ICU of La Pitié Salpetrière Hospital, Paris, France. DP is a professor in the ICU of the Alfred Hospital, Melbourne, Australia. AC is a professor and the head of the Medical ICU of La Pitié Salpetrière Hospital Paris, France. MS is an assistant professor in the Medical ICU of La Pitié Salpetrière Hospital Paris, France.}

\section{Competing interests}

SR and DP have no conflicts of interest to declare. AC is the primary investigator of the EOLIA trial (NCT01470703), a randomized trial of W-ECMO supported in part by MAQUET, and has received honoraria for lectures from MAQUET. MS reports receiving lecture honoraria from Maquet.

\section{Consent for publication}

Not applicable.

Ethics approval and consent to participate

Not applicable.

\section{Author details}

'Sorbonne Universités, UPMC Univ Paris 06, INSERM, UMRS_1166-ICAN, Institute of Cardiometabolism and Nutrition, 75651 Paris Cedex 13, France. ${ }^{2}$ Assistance Publique-Hôpitaux de Paris, Pitié-Salpêtrière Hospital, Medical Intensive Care Unit, 75651 Paris Cedex 13, France. ${ }^{3}$ Australian and New Zealand Intensive Care Research Centre, Department of Epidemiology and 
Preventive Medicine, School of Public Health, Monash University, Melbourne, Australia. ${ }^{4}$ Intensive Care Department, Alfred Hospital, Melbourne, Australia.

\section{Published online: 05 December 2016}

\section{References}

1. Brodie D, Bacchetta M. Extracorporeal membrane oxygenation for ARDS in adults. N Engl J Med. 2011;365:1905-14.

2. ESLO Guidelines-Adult. http:/www.elso.org/Portals/0/GD/Archive/FileManager/ 989d4d4d14cusersshyerdocumentselsoguidelinesforadultrespiratonffailure1.3.pdf. Accessed 1 Nov 2016

3. ELSO ECLS Registry Report. http://www.elso.org. Accessed 23 Aug 2016.

4. Peek GJ, Mugford M, Tiruvoipati R, Wilson A, Allen E, Thalanany MM, Hibbert CL, Truesdale A, Clemens F, Cooper N, Firmin RK, Elbourne D, CESAR Trial Collaboration. Efficacy and economic assessment of conventional ventilatory support versus extracorporeal membrane oxygenation for severe adult respiratory failure (CESAR): a multicentre randomised controlled trial. Lancet. 2009:374:1351-63.

5. MacLaren G, Combes A, Bartlett RH. Contemporary extracorporeal membrane oxygenation for adult respiratory failure: life support in the new era. Intensive Care Med. 2012;38:210-20.

6. Schmidt M, Zogheib E, Rozé H, Repesse X, Lebreton G, Luyt C-E, Trouillet J-L, Bréchot N, Nieszkowska A, Dupont H, Ouattara A, Leprince P, Chastre J, Combes A. The PRESERVE mortality risk score and analysis of long-term outcomes after extracorporeal membrane oxygenation for severe acute respiratory distress syndrome. Intensive Care Med. 2013:39:1704-13.

7. Zangrillo A, Landoni G, Biondi-Zoccai G, Greco M, Greco T, Frati G, Patronit N, Antonelli M, Pesenti A, Pappalardo F. A meta-analysis of complications and mortality of extracorporeal membrane oxygenation. Crit Care Resusc. 2013:15:172-8

8. Cooper E, Burns J, Retter A, Salt G, Camporota L, Meadows CIS, Langrish CCJ, Wyncoll D, Glover G, loannou N, Daly K, Barrett NA. Prevalence of venous thrombosis following venovenous extracorporeal membrane oxygenation in patients with severe respiratory failure. Crit Care Med. 2015;43:e581-4

9. Noah MA, Peek GJ, Finney SJ, Griffiths MJ, Harrison DA, Grieve R, Sadique MZ, Sekhon JS, McAuley DF, Firmin RK, Harvey C, Cordingley JJ, Price S, Vuylsteke A, Jenkins DP, Noble DW, Bloomfield R, Walsh TS, Perkins GD, Menon D, Taylor BL, Rowan KM. Referral to an extracorporeal membrane oxygenation center and mortality among patients with severe 2009 influenza A(H1N1). JAMA. 2011;306:1659-10.

10. Roch A, Lepaul-Ercole R, Grisoli D, Bessereau J, Brissy O, Castanier M, Dizier S, Forel J-M, Guervilly C, Gariboldi V, Collart F, Michelet P, Perrin G, Charrel R, Papazian L. Extracorporeal membrane oxygenation for severe influenza $A$ (H1N1) acute respiratory distress syndrome: a prospective observational comparative study. Intensive Care Med. 2010;36:1899-905.

11. Camboni D, Philipp A, Lubnow M, Bein T, Haneya A, Diez C, Schmid C, Müller T. Support time-dependent outcome analysis for veno-venous extracorporeal membrane oxygenation. Eur J Cardiothorac Surg. 2011:40:1341-7.

12. ARDS Definition Task Force, Ranieri VM, Rubenfeld GD, Thompson BT, Ferguson ND, Caldwell E, Fan E, Camporota L, Slutsky AS. Acute respiratory distress syndrome: the Berlin Definition. Am Med Assoc. 2012;307:2526-33.

13. Matthay MA, Zemans RL. The acute respiratory distress syndrome: pathogenesis and treatment. Annu Rev Pathol. 2011;6:147-63.

14. Matthay MA. Resolution of pulmonary edema. Thirty years of progress. Am J Respir Crit Care Med. 2014;189:1301-8.

15. Matthay MA, Zimmerman GA. Acute lung injury and the acute respiratory distress syndrome: four decades of inquiry into pathogenesis and rational management. Am J Respir Cell Mol Biol. 2005;33:319-27.

16. Dreyfuss D, Saumon G. Ventilator-induced lung injury: lessons from experimental studies. Am J Respir Crit Care Med. 1998;157:294-323.

17. Slutsky AS, Ranieri VM. Ventilator-Induced Lung Injury. N Engl J Med. 2013;369:2126-36.

18. Network A. Ventilation with lower tidal volumes as compared with traditional tidal volumes for acute lung injury and the acute respiratory distress syndrome. The Acute Respiratory Distress Syndrome Network. N Engl J Med. 2000;342:1301-8.

19. Guérin $C$, Reignier J, Richard J-C, Beuret $P$, Gacouin A, Boulain T, Mercier E, Badet M, Mercat A, Baudin O, Clavel M, Chatellier D, Jaber S, Rosselli S, Mancebo J, Sirodot M, Hilbert G, Bengler C, Richecoeur J, Gainnier M, Bayle
F, Bourdin G, Leray V, Girard R, Baboi L, Ayzac L, PROSEVA Study Group. Prone positioning in severe acute respiratory distress syndrome. N Engl J Med. 2013;368:2159-68.

20. Papazian L, Forel J-M, Gacouin A, Penot-Ragon C, Perrin G, Loundou A, Jaber S, Arnal J-M, Perez D, Seghboyan J-M, Constantin J-M, Courant P, Lefrant J-Y, Guérin C, Prat G, Morange S, Roch A. ACURASYS Study Investigators. Neuromuscular blockers in early acute respiratory distress syndrome. N Engl J Med. 2010;363:1107-16.

21. Phua J, Badia JR, Adhikari NK, Friedrich JO, Fowler RA, Singh JM, Scales DC, Stather DR, Li A, Jones A, Gattas DJ, Hallett D, Tomlinson G, Stewart $T E$, Ferguson ND. Has mortality from acute respiratory distress syndrome decreased over time?: a systematic review. Am J Respir Crit Care Med. 2009:179:220-7.

22. Young D, Lamb SE, Shah S, MacKenzie I, Tunnicliffe W, Lall R, Rowan K, Cuthbertson BH, OSCAR Study Group. High-frequency oscillation for acute respiratory distress syndrome. N Engl J Med. 2013;368:806-13.

23. Ferguson ND, Cook DJ, Guyatt GH, Mehta S, Hand L, Austin P, Zhou Q, Matte A, Walter SD, Lamontagne F, Granton JT, Arabi YM, Arroliga AC, Stewart TE, Slutsky AS, Meade MO, OSCILLATE Trial Investigators, Canadian Critical Care Trials Group. High-frequency oscillation in early acute respiratory distress syndrome. N Engl J Med. 2013;368:795-805.

24. Herridge MS, Tansey CM, Matte A, Tomlinson G, Diaz-Granados N, Cooper A, Guest CB, Mazer CD, Mehta S, Stewart TE, Kudlow P, Cook D, Slutsky AS, Cheung AM, Canadian Critical Care Trials Group. Functional disability 5 years after acute respiratory distress syndrome. N Engl J Med. 2011;364:1293-304.

25. Brogan TV, Thiagarajan RR, Rycus PT, Bartlett RH, Bratton SL. Extracorporeal membrane oxygenation in adults with severe respiratory failure: a multicenter database. Intensive Care Med. 2009;35:2105-14.

26. Australia and New Zealand Extracorporeal Membrane Oxygenation (ANZ ECMO) Influenza Investigators, Davies A, Jones D, Bailey M, Beca J, Bellomo R, Blackwell N, Forrest P, Gattas D, Granger E, Herkes R, Jackson A, McGuinness S, Nair P, Pellegrino V, Pettilä V, Plunkett B, Pye R, Torzillo P, Webb S, Wilson M, Ziegenfuss M. Extracorporeal membrane oxygenation for 2009 influenza A(H1N1) acute respiratory distress syndrome. JAMA. 2009;302:1888-95

27. Schmidt M, Bailey M, Sheldrake J, Hodgson C, Aubron C, Rycus PT, Scheinkestel C, Cooper DJ, Brodie D, Pellegrino V, Combes A, Pilcher D. Predicting survival after extracorporeal membrane oxygenation for severe acute respiratory failure. The Respiratory Extracorporeal Membrane Oxygenation Survival Prediction (RESP) Score. Am J Respir Crit Care Med. 2014;189:1374-82

28. Roch A, Hraiech S, Masson E, Grisoli D, Forel J-M, Boucekine M, Morera P, Guervilly C, Adda M, Dizier S, Toesca R, Collart F, Papazian L. Outcome of acute respiratory distress syndrome patients treated with extracorporeal membrane oxygenation and brought to a referral center. Intensive Care Med. 2014:40:74-83.

29. Lindén VB, Lidegran MK, Frisén G, Dahlgren P, Frenckner BP, Larsen F. ECMO in ARDS: a long-term follow-up study regarding pulmonary morphology and function and health-related quality of life. Acta Anaesthesiol Scand. 2009:53:489-95.

30. Li X-Y, Sun B, Wang C-T, He H-Y, Zhang C-Y, Ding Y, Peng P, Tong Z-H, Zhan Q-Y. A follow-up study on acute respiratory distress syndrome survivors after extracorporeal membrane oxygenation by pulmonary highresolution CT. Arch Iran Med. 2015;18:6-11.

31. Luyt C-E, Combes A, Becquemin M-H, Beigelman-Aubry C, Hatem S, Brun A-L, Zraik N, Carrat F, Grenier PA, Richard J-CM, Mercat A, Brochard L, Brun-Buisson C, Chastre J, REVA Study Group. Long-term outcomes of pandemic 2009 influenza A(H1N1)-associated severe ARDS. Chest. 2012;142:583-92

32. McHorney CA, Ware JE, Lu JF, Sherbourne CD. The MOS 36-item Short-Form Health Survey (SF-36): III. Tests of data quality, scaling assumptions, and reliability across diverse patient groups. Med Care. 1994;32:40-66.

33. Hodgson CL, Hayes K, Everard T, Nichol A, Davies AR, Bailey MJ, Tuxen DV, Cooper DJ, Pellegrino V. Long-term quality of life in patients with acute respiratory distress syndrome requiring extracorporeal membrane oxygenation for refractory hypoxaemia. Crit Care. 2012;16:R202.

34. Bienvenu OJ, Colantuoni E, Mendez-Tellez PA, Dinglas VD, Shanholtz C, Husain N, Dennison CR, Herridge MS, Pronovost PJ, Needham DM. Depressive symptoms and impaired physical function after acute lung injury. Am J Respir Crit Care Med. 2012;185:517-24. 
35. Ringdal M, Plos K, Örtenwall P, Bergbom I. Memories and health-related quality of life after intensive care: a follow-up study. Crit Care Med. 2010;38:38-44

36. Myhren $\mathrm{H}$, Ekeberg $\varnothing$, Stokland $O$. Health-related quality of life and return to work after critical illness in general intensive care unit patients: a 1-year follow-up study. Crit Care Med. 2010;38:1554-61.

37. Munshi L, Telesnicki T, Walkey A, Fan E. Extracorporeal life support for acute respiratory failure. A systematic review and metaanalysis. Ann Am Thorac Soc. 2014;11:802-10

38. Ried M, Bein T, Philipp A, Müller T, Graf B, Schmid C, Zonies D, Diez C, Hofmann H-S. Extracorporeal lung support in trauma patients with severe chest injury and acute lung failure: a 10-year institutional experience. Crit Care. 2013;17:R110

39. Cheung PY, Sawicki G, Salas E, Etches PC, Schulz R, Radomski MW. The mechanisms of platelet dysfunction during extracorporeal membrane oxygenation in critically ill neonates. Crit Care Med. 2000;28:2584-90.

40. Heilmann C, Geisen U, Beyersdorf F, Nakamura L, Benk C, Trummer G, Berchtold-Herz M, Schlensak C, Zieger B. Acquired von Willebrand syndrome in patients with extracorporeal life support (ECLS). Intensive Care Med. 2012;38:62-8.

41. Tauber H, Ott H, Streif W, Weigel G, Loacker L, Fritz J, Heinz A, VelikSalchner C. Extracorporeal membrane oxygenation induces short-term loss of high-molecular-weight von Willebrand factor multimers. Anesth Analg. 2015;120:730-6.

42. Abrams D, Baldwin MR, Champion M, Agerstrand C, Eisenberger A, Bacchetta M, Brodie D. Thrombocytopenia and extracorporeal membrane oxygenation in adults with acute respiratory failure: a cohort study. Intensive Care Med. 2016:42:844-52.

43. Aubron C, Cheng AC, Pilcher D, Leong T, Magrin G, Cooper DJ, Scheinkestel C, Pellegrino V. Factors associated with outcomes of patients on extracorporeal membrane oxygenation support: a 5-year cohort study. Crit Care. 2013;17:R73

44. Agerstrand CL, Burkart KM, Abrams DC, Bacchetta MD, Brodie D. Blood conservation in extracorporeal membrane oxygenation for acute respiratory distress syndrome. Ann Thorac Surg. 2015;99:590-5.

45. Aubron C, Cheng AC, Pilcher D, Leong T, Magrin G, Cooper DJ, Scheinkestel C, Pellegrino $\mathrm{V}$. Infections acquired by adults who receive extracorporeal membrane oxygenation: risk factors and outcome. Infect Control Hosp Epidemiol. 2013;34:24-30.

46. Schmidt $M$, Bréchot $N$, Hariri S, Guiguet $M$, Luyt C-E, Makri R, Leprince $P$, Trouillet J-L, Pavie A, Chastre J, Combes A. Nosocomial infections in adult cardiogenic shock patients supported by venoarterial extracorporeal membrane oxygenation. Clin Infect Dis. 2012;55:1633-41.

47. Hsu MS, Chiu KM, Huang YT, Kao KL, Chu SH, Liao CH. Risk factors for nosocomial infection during extracorporeal membrane oxygenation. J Hosp Infect. 2009;73:210-6.

48. Sun $\mathrm{H}-\mathrm{Y}$, Ko W-J, Tsai P-R, Sun C-C, Chang Y-Y, Lee C-W, Chen Y-C. Infections occurring during extracorporeal membrane oxygenation use in adult patients. J Thorac Cardiovasc Surg. 2010;140:1125-32.e2

49. Bizzarro MJ, Conrad SA, Kaufman DA, Rycus P, Extracorporeal Life Support Organization Task Force on Infections, Extracorporeal Membrane Oxygenation. Infections acquired during extracorporeal membrane oxygenation in neonates, children, and adults. Pediatr Crit Care Med. 2011;12:277-81

50. Kao LS, Fleming GM, Escamilla RJ, Lew DF, Lally KP. Antimicrobial prophylaxis and infection surveillance in extracorporeal membrane oxygenation patients: a multi-institutional survey of practice patterns. ASAIO J. 2011;57:231-8.

51. Luyt C-E, Bréchot N, Demondion P, Jovanovic T, Hekimian G, Lebreton G, Nieszkowska A, Schmidt M, Trouillet J-L, Leprince P, Chastre J, Combes A. Brain injury during venovenous extracorporeal membrane oxygenation. Intensive Care Med. 2016:42:897-907.

52. Lou S, MacLaren G, Best D, Delzoppo C, Butt W. Hemolysis in pediatric patients receiving centrifugal-pump extracorporeal membrane oxygenation: prevalence, risk factors, and outcomes. Crit Care Med. 2014;42:1213-20.

53. Pappalardo F, Pieri M, Greco T, Patroniti N, Pesenti A, Arcadipane A, Ranieri VM, Gattinoni L, Landoni G, Holzgraefe B, Beutel G, Zangrillo A. Italian ECMOnet. Predicting mortality risk in patients undergoing venovenous ECMO for ARDS due to influenza A (H1N1) pneumonia: the ECMOnet score. Intensive Care Med. 2013;39:275-81.

54. Enger T, Philipp A, Videm V, Lubnow M, Wahba A, Fischer M, Schmid C, Bein T, Müller T. Prediction of mortality in adult patients with severe acute lung failure receiving veno-venous extracorporeal membrane oxygenation: a prospective observational study. Crit Care. 2014;18:R67.

55. Liu X, Xu Y, Zhang R, Huang Y, He W, Sang L, Chen S, Nong L, Li X, Mao P, Li Y. Survival predictors for severe ARDS patients treated with extracorporeal membrane oxygenation: a retrospective study in China. PLoS One. 2016;11:e0158061-14.

56. Cheng Y-T, Wu M-Y, Chang Y-S, Huang C-C, Lin PJ. Developing a simple preinterventional score to predict hospital mortality in adult venovenous extracorporeal membrane oxygenation: a pilot study. Medicine (Baltimore). 2016;95:e4380

57. Chang W-W, Tsai F-C, Tsai T-Y, Chang C-H, Jeng C-C, Chang M-Y, Tian Y-C, Hung C-C, Fang J-T, Yang C-W, Chen Y-C. Predictors of mortality in patients successfully weaned from extracorporeal membrane oxygenation. PLoS One. 2012;7:e42687.

58. Wu M-Y, Lin PJ, Tsai F-C, Haung Y-K, Liu K-S, Tsai F-C. Impact of preexisting organ dysfunction on extracorporeal life support for non-postcardiotomy cardiopulmonary failure. Resuscitation. 2008;79:54-60.

59. Barbaro RP, Odetola FO, Kidwell KM, Paden ML, Bartlett RH, Davis MM, Annich GM. Association of hospital-level volume of extracorporeal membrane oxygenation cases and mortality. Analysis of the extracorporeal life support organization registry. Am J Respir Crit Care Med. 2015;191:894-901.

60. Kleinzing S, Wenger U, Steiger $P$, Starck CT, Wilhelm M, Schuepbach RA, Maggiorini M. External validation of scores proposed for estimation of survival probability of patients with severe adult respiratory distress syndrome undergoing extracorporeal membrane oxygenation therapy: a retrospective study. Crit Care. 2015;19:142. 